\title{
Toxicity to sea urchin egg development of the quinone fraction obtained from Auxemma oncocalyx
}

\footnotetext{
L.V. Costa-Lotufo' ${ }^{1}$, M.A.D. Ferreira ${ }^{1}$, T.L.G. Lemos², O.D.L. Pessoa²,

G.S.B. Viana ${ }^{1}$ and G.M.A. Cunha ${ }^{1}$
}

\author{
Departamentos de ${ }^{1}$ Fisiologia e Farmacologia, Faculdade de Medicina, and \\ ${ }^{2} Q$ uímica O rgânica e Inorgânica, U niversidade Federal do Ceará, \\ Fortaleza, CE, Brasil
}

\section{Correspondence \\ L.V. Costa-Lotufo \\ Departamento de Fisiologia \\ e Farmacologia, UFC \\ Rua Coronel Nunes de Melo, 1127 \\ 60430-270 Fortaleza, CE \\ Brasil \\ Fax: + 55-85-288-8333 \\ E-mail: Ivcosta@ secrel.com.br}

Received October 29, 2001

Accepted June 20, 2002

\section{Abstract}

Auxemma oncocalyx Taub. belongs to the Boraginaceae family and is native to the Brazilian northeast where it is known as "pau-branco". We investigated the ability of the water soluble fraction isolated from the heartwood of $A$. oncocalyx to inhibit sea urchin egg development. This fraction contains about $80 \%$ oncocalyxone A (quinone fraction), a compound known to possess strong cytotoxic and antitumor activities. In fact, the quinone fraction inhibited cleavage in a dose-dependent manner $\left[\mathrm{IC}_{50}\right.$ of $\left.18.4(12.4-27.2) \mu \mathrm{g} / \mathrm{ml}, \mathrm{N}=6\right]$, and destroyed the embryos in the blastula stage [ $\mathrm{IC}_{50}$ of $\left.16.2(13.7-19.2) \mu \mathrm{g} / \mathrm{ml}, \mathrm{N}=6\right]$. We suggest that this activity is due to the presence of oncocalyxone A. In fact, these quinones present in $A$. oncocalyx extract have strong toxicity related to their antimitotic activity.

Auxemma oncocalyx Taub. belongs to the Boraginaceae family. It is known as "pau branco" and is frequently found in the State of Ceará, Northeastern Brazil. The bark of the tree is an astringent and is popularly used in the treatment of wounds (1). A $\beta$-sitosterol glycoside and allantoin, probably responsible for the activity related to its popular use, have been isolated from the plant (2). At least seven quinones were also isolated $(3,4)$. Pharmacological studies have revealed that the alcoholic extract of the stem presents analgesic and antiedematogenic (5), antitumoral (6), and antiplatelet (7) activities. Over the last few years, antiplatelet activity of the quinone fraction from the heartwood of $A$. oncocalyx (8) and antitumoral activity of

\section{Key words}

- Auxemma oncocalyx

- Quinones

- Sea urchin eggs

- Oncocalyxone A oncocalyxones $\mathrm{A}$ and $\mathrm{C}$, quinones isolated from the plant $(9,10)$, were demonstrated. The antitumoral activity was verified as the ability of oncocalyxone A to inhibit tumor cell line proliferation in the MTT [3-(4'-5'dimethylthiazol-2'-yl)-2,5-diphenyl-tetrazolium bromide] assay, and this cytotoxicity was related to the induction of DNA damage and the inhibition of DNA synthesis $(9,10)$. Finally, these authors suggested that this compound had moderate anticancer potential (10).

The study of alterations in sea urchin egg development is a suitable model for detecting the cytotoxic, teratogenic and antineoplastic activities of new compounds. Sea urchin eggs have also been extensively used as a model for developmental toxicology 
evaluation (11-13). The objective of the present study was to investigate the effect of the quinone fraction from the heartwood of $A$. oncocalyx on sea urchin egg development to determine its effects on cell division and also on embryo development.

Samples of A. oncocalyx were collected in the town of Pentecoste, State of Ceará, Brazil. A voucher specimen (\# 18459) identified by Dr. A.G. Fernandes (Department of Biology, Federal University of Ceará) has been deposited at the Prisco Bezerra Herbarium of the Federal University of Ceará, Brazil. The quinone fraction $(2.5 \mathrm{~g})$ was prepared from a ground heartwood ethanol extract $(10.0 \mathrm{~g})$ by exhaustive aqueous extraction followed by lyophilization, and was suspended in $1 \%$ dimethylsulfoxide before the assays. The vehicle was used as negative control.

For the sea urchin egg development tests, specimens of Lytechinus variegatus were collected from Pecém beach, west coast of Ceará State. Gamete elimination was induced by injecting $3.0 \mathrm{ml}$ of a $0.5 \mathrm{M} \mathrm{KCl}$ solution into the perivisceral cavity. The eggs were allowed to settle to the bottom of a graduate cylinder filled with filtered sea water. This process was repeated twice to wash off the jelly coat of the eggs. Concentrated sperm was collected with a Pasteur pipette. Egg fertilization was performed by adding $1 \mathrm{ml}$ of a sperm suspension $(0.01 \mathrm{ml}$ of concentrated sperm plus $2.49 \mathrm{ml}$ of filtered sea

Figure 1. Effect of the quinone fraction from Auxemma oncocalyx on sea urchin egg cleavage. Data are reported as the mean \pm SEM of 6 experiments for the first (circles) and third (squares) cleavages and blastulae (lozenges). The curve was obtained by nonlinear regression. The negative control consisted of the vehicle used for suspension of the tested substance.

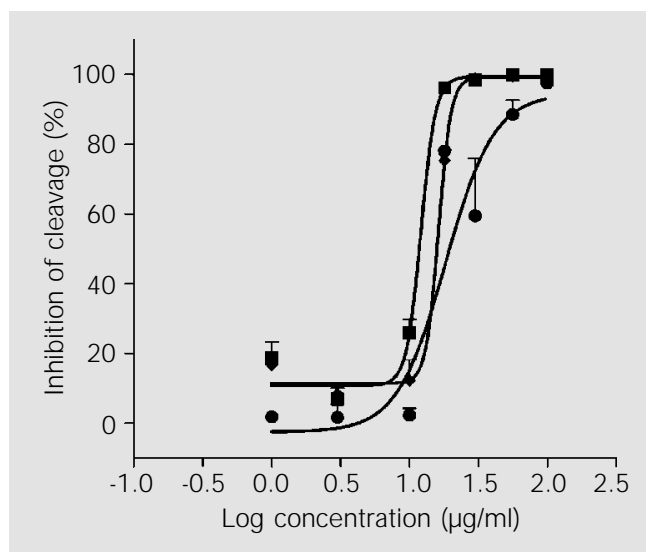

water) to $100 \mathrm{ml}$ of filtered sea water containing the eggs. Fecundation was confirmed by the elevation of the vitellin membrane. Next, the eggs were distributed in 24-well plates, with each well receiving $1 \mathrm{ml}$ of the egg suspension (13). Five minutes after fertilization, the quinone fraction was added at concentrations ranging from 1 to $100 \mu \mathrm{g} / \mathrm{ml}$. The eggs were incubated in a final volume of $2 \mathrm{ml}$, and the plates were shaken in a water bath at room temperature $\left(26 \pm 2^{\circ} \mathrm{C}\right)$. At appropriate times, $200-\mu 1$ aliquots were fixed in the same volume of $10 \%$ formaldehyde to obtain first and third cleavages, and blastulae. One hundred eggs or embryos were counted for each concentration of the tested substances in order to obtain the percentage of normal development. Data are reported as means \pm SEM for $N$ independent experiments. The $\mathrm{IC}_{50}$ and its $95 \%$ confidence interval were obtained by nonlinear regression using the Graph Pad Prism program version 2.01 (Intuitive Software for Science, San Diego, CA, USA).

The quinone fraction induced a concentration-dependent inhibition of sea urchin egg development (Figure 1). The $\mathrm{IC}_{50}$ values for the first and third cleavages and for the blastulae were 18.4 (12.4-27.2), 12.1 (10.813.6) and $16.2(13.7-19.2) \mu \mathrm{g} / \mathrm{ml}$, respectively. In fact, the quinone fraction was extremely toxic to sea urchin cells. At the third cleavage, it induced abnormalities in the cells and at the blastula stage it caused destruction of the embryos starting at the concentration of $10 \mu \mathrm{g} / \mathrm{ml}$, with total embryo destruction $(100 \%)$ at the concentration of $30 \mu \mathrm{g} / \mathrm{ml}$ (Figure 2), an effect which seemed to involve membrane disruption.

Sea urchin egg development showed some peculiarities that permit us to suggest how the test substances acted. The sea urchin cell cycle was dramatically reduced, essentially cycling from $\mathrm{S}$ (synthesis) to $\mathrm{M}$ (mitosis) and the S phase showed no G1 and a relatively short G2 phase (12). The quinone fraction-induced inhibition occurred at the 
A

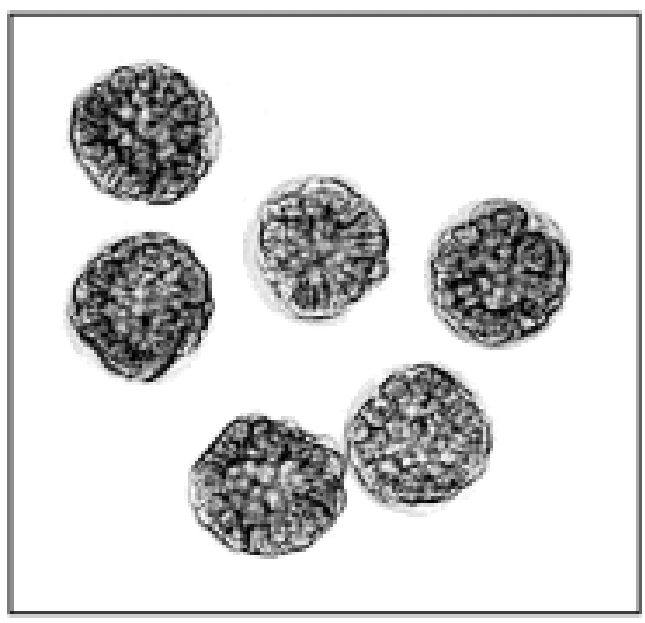

first cleavage of the sea urchin egg development. The inhibition of the first cleavage in these cells is related to DNA and/or protein synthesis or microtubule assembling, since RNA synthesis is very slow or absent after fertilization (14). At this time, the rapid increase in the rate of protein synthesis is largely due to the recruitment of maternal mRNA into polysomes (15). However, when a substance blocks microtubule assembling, clear spots corresponding to nucleus duplication can be observed in the cytoplasm. Since cells treated with the quinone fraction presented a homogenous cytoplasm, this process appears not have been affected (12). Hence, the quinone fraction might be affecting DNA and/or protein synthesis.

HPLC analysis of the quinone fraction revealed that water soluble components contained about $80 \%$ oncocalyxone A, an 1,4anthracenedione, previously isolated from the water alcohol extract of the bark of $A$. oncocalyx $(3,4)$. Oncocalyxone A showed antimicrobial activity $(3,4)$ and cytotoxicity against CEM, SW1573 and CCD922 human cell lines $(9,10)$. Pessoa et al. (9) demonstrated that oncocalyxone A caused substantial DNA damage and marked inhibition of 5-bromo-2'-deoxyuridine incorporation during cell duplication, concluding that its cytotoxicity is related to its effects on DNA
B

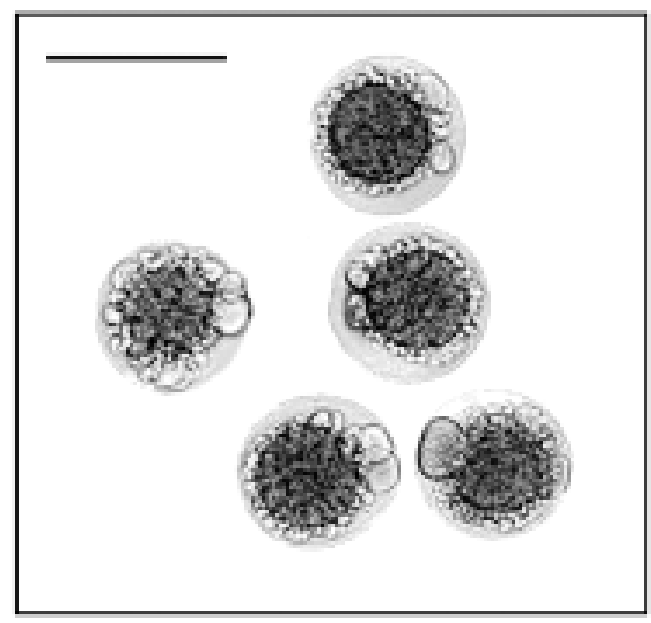

integrity and DNA synthesis. This evidence strongly suggests that oncocalyxone A present in the quinone fraction could be responsible for the observed effect on sea urchin cells, and that this effect is probably related to its DNA damaging properties.

Leyva et al. (10) showed that oncocalyxones $\mathrm{A}$ and $\mathrm{C}$, both isolated from $\mathrm{A}$. oncocalyx, were also cytotoxic to multidrug resistant lung tumor cell lines (SW 1573, SW 1573-S1, SW 1573-2R160), which were moderately or even highly resistant to the conventional anticancer drugs doxorubicin and mitoxantrone. It is important to point out that the oncocalyxone compounds do not possess selectivity against different cells, as shown by the $\mathrm{IC}_{50}$ values obtained in different models including sea urchin eggs. Moreover, the present data showed that, despite its antimitotic activity, the quinone fraction induced embryo destruction at the same concentration at which it inhibited tumor cell proliferation $\left(\mathrm{IC}_{50}\right.$ around $\left.10 \mu \mathrm{g} / \mathrm{ml}\right)$, indicating that this compound may be too toxic to be used as an antitumoral drug.

Since quinones may be mutagenic and carcinogenic, the cytotoxicity associated with these compounds can be attributed to redox cycling and subsequent development of oxidative stress (16). Thus, the cellular damage can occur by DNA alkylation (17). Conse-
Figure 2. Photomicrographs showing the effect of the quinone fraction from Auxemma oncocalyx at the blastula stage of the sea urchin egg development. A, Control and B, cells treated with $100 \mu \mathrm{g} / \mathrm{ml}$ of the quinone fraction. $B a r=100 \mu \mathrm{m}$. 
quently, quinones have a high toxicity related to their antimitotic properties, which would probably limit in vivo studies and the determination of the anticancer potential of these compounds. Besides, these quinones present in the A. oncocalyx extract could be considered as potential lead compounds from which some derivatives with high antimitotic activity but lower toxicity could be produced.

\section{References}

1. Braga R (1976). Plantas do Nordeste, Especialmente do Ceará. Editora Universitária da UFRN (Coleção Mossoroense, 3), Fortaleza, CE, Brazil.

2. Pessoa ODL \& Lemos TLG (1997). Allantoin and fatty acid composition in Auxemma oncocalyx. Revista Brasileira de Farmácia, 78: 9-10.

3. Pessoa ODL, Lemos TLG, Silveira ER \& Braz-Filho R (1993). Novel cordiachromes isolated from Auxemma oncocalyx. Natural Products Letters, 2: 145-150.

4. Pessoa ODL, Lemos TLG, De Carvalho MG \& Braz-Filho R (1995). Cordiachromes from Auxemma oncocalyx. Phytochemistry, 40: 1777-1786.

5. Lino CS, Pessoa ODL, Lemos TLG \& Viana GSB (1996). Estudo da atividade analgésica e antiedematogênica do extrato de Auxemma oncocalyx e oncocalyxona A. XIV Simpósio de Plantas Medicinais do Brasil, September 17-20, Florianópolis, SC, Brazil, 95.

6. Pessoa C, Mendes CS, Pessoa ODL, Sabino SH, Lemos TL \& Moraes MO (1992). Avaliação da atividade antitumoral de Auxemma oncocalyx Taub. (Pau Branco). VII Annual Meeting of the Federação de Sociedades de Biologia Experimental, Caxambu, MG, Brazil, August 2629, 168.
7. Fontenele J B \& Souza DC (1992). Efeitos de Hymenaea coubaril Linn., Auxemma oncocalyx Taub., Torresea cearensis, Fr. All. e J atropha gossypifolia Linn. sobre a agregação plaquetária. XI Encontro Universitário de Iniciação à Pesquisa, December 3-4, Fortaleza, CE, Brazil, 128.

8. Ferreira $M A D$, Nunes $O D R H$, Fujimura AHY, Pessoa ODL, Lemos TLG \& Viana GSB (1999). Inhibition of platelet activation by quinones isolated from Auxemma oncocalyx Taub. Research Communications in Molecular Pathology and Pharmacology, 106: 97-107.

9. Pessoa C, Silveira ER, Lemos TLG, Wetmore LA, Moraes MO \& Leyva A (2000). Antiproliferative effects of compounds derived from plants of Northeast Brazil. Phytotherapy Research, 14: 187191.

10. Leyva A, Pessoa C, Boogaerdt F, Sokaroski R, Lemos TLG, Wetmore LA, Huruta RR \& Moraes MO (2000). Oncocalyxones $A$ and $C, 1,4$-anthracenediones from Auxemma oncocalyx: Comparison with anticancer 1,9-anthracenediones. Anticancer Research, 20: 1029-1031.

11. Fusetani N (1987). Marine metabolities which inhibit development of echinoderm embryos. In: Scheuer P (Editor), Bioorganic Marine Chemistry. Springer-Verlag,
Berlin, Germany.

12. J acobs RS \& Wilson L (1986). Fertilized sea urchin egg as a model for detecting cell division inhibitors. In: Aszalor A (Editor), Modern Analysis of Antibiotics. Marcel Dekker, Inc., New York, NY, USA.

13. Malpezzi ELA, Davino SC, Costa LV, Freitas J C, Giesbrecht AM \& Roque NF (1994). Antimitotic action of extracts of Petiveria alliacea on sea urchin egg development. Brazilian J oumal of Medical and Biological Research, 27: 749-754.

14. Gross PR, Malkin J L \& Moyer WA (1964). Templates for the first proteins of embryonic development. Proceedings of the $\mathrm{Na}$ tional Academy of Sciences, USA, 51: 407-414.

15. Brandhorst BP (1985). Informational content of the echinoderm egg. In: Browder LW (Editor), Developmental Biology, a Comprehensive Synthesis. Oogenesis. Plenum Press, New York, NY, USA.

16. Monks TJ \& Lau SS (1992). Toxicology of quinone-thioethers. Critical Reviews in Toxicology, 22: 243-270.

17. Bolton J L, Trush MA, Penning TM, Dryhurst G \& Monks TJ (2000). Role of quinones in toxicology. Chemical Research in Toxicology, 13: 135-160. 